\title{
The District Supervision of the LOCOMOTIVE DEPARTMENT OF AN INDIAN RaILWAY.
}

Paper read before the Institution ly H. P. RENITICK, Member, Secunderabad, India, on igth October, 1922, in London.

\section{PAPER No. 130.}

The Author, in presenting this Paper, has endeavoured to place before the members of the Institution a resume of the usual methods adopted in the administration of the 
locomotive department of an Indian railway and some of the peculiar difficulties and perplexities that are the daily lot of the Divisional Superintendent.

It is hoped that the Paper will be of especial interest to the junior members of the Institution who are offered posts in India, in giving them some idea of what they will be "up against."

In the first place it is essential to get a correct view of the country itself.

India is a country of large distances, roughly triangular in shape, the base from East to West, or along a straight line drawn from Karachi to Dibrugarh in Assam, being $\mathrm{I}, 79^{2}$ miles; and from the base to apex, or along a straight line from Peshawar in the North to Tuticovin in the South, I, $83_{2}$ miles.

In this area there is a population of 320 millions of people of nearly 300 castes, most of whom differ greatly in their general characteristics, speak different languages and adopt different religions.

There is as much difference between a Canarese or Madrassi of the South and a Pathan or Punjabi of the North-West, or again between a Bengali of the North East and a Mahratti of the West as between a Spaniard and a Russian or a Greek and a Scandinavian.

A good deal of migration occurs, so that the railway staff at any centre is generally composed of men from different parts of the country.

The four basic religions are Hindu, Mussulman, Christian and Parsi or Zoroastrian, and as religion plays a large part in the daily life of the native population, religious susceptibilities must be considered in handling the staffs.

Climatic and temperature variations in different parts of the country play an important part in the question of work output, train running and traffic. No general statement can be given of the weather in the country as a whole, but to reduce this question to its simplest form it will be sufficient to divide the country into zones, as follows :- 
AVERAGE MONTHLY MEAN TEMPERATURE AND RAINFALL IN INDIA.

Temperature in Degrees Fahrenheit.

Rainfall in inches.

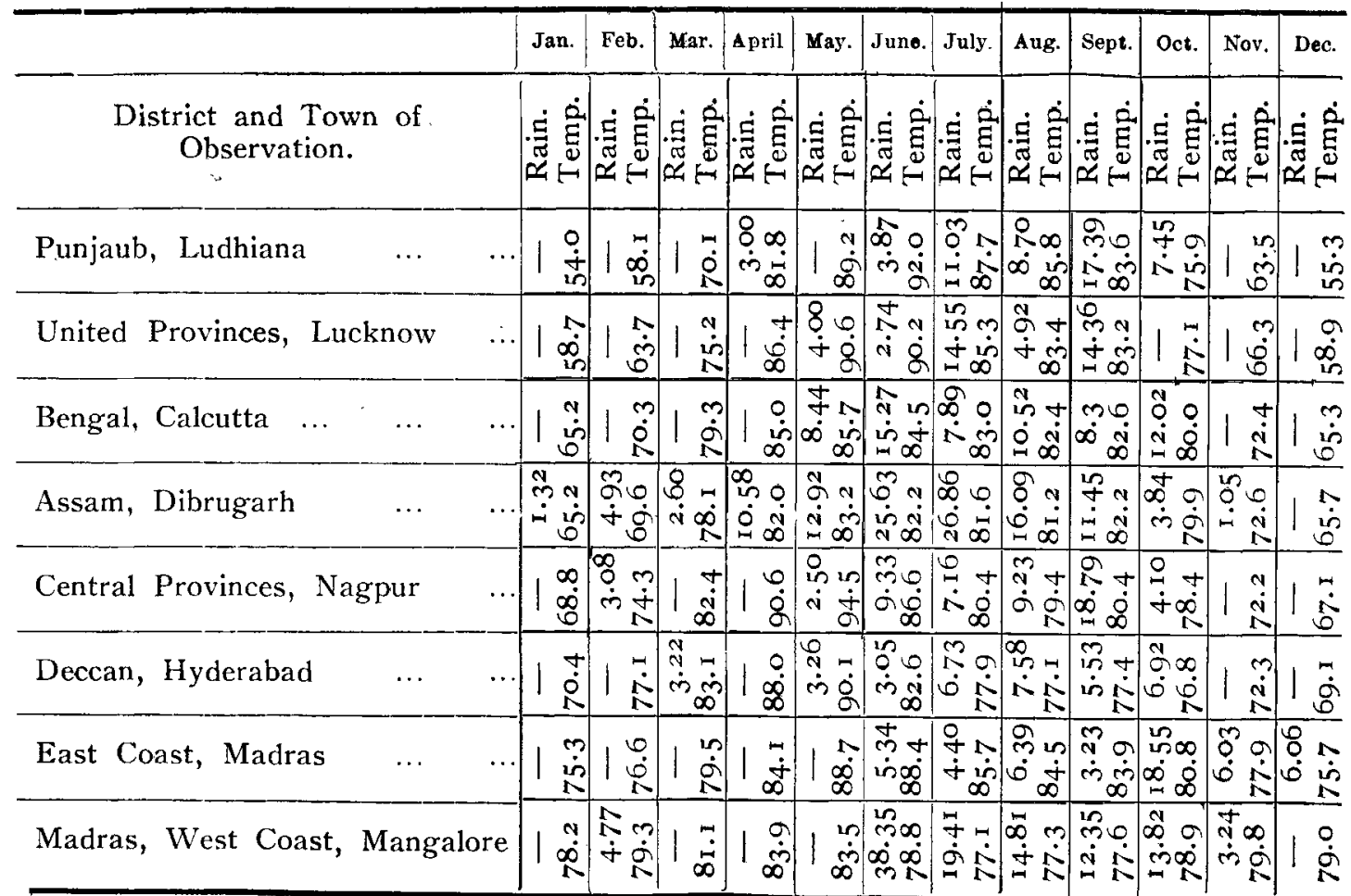




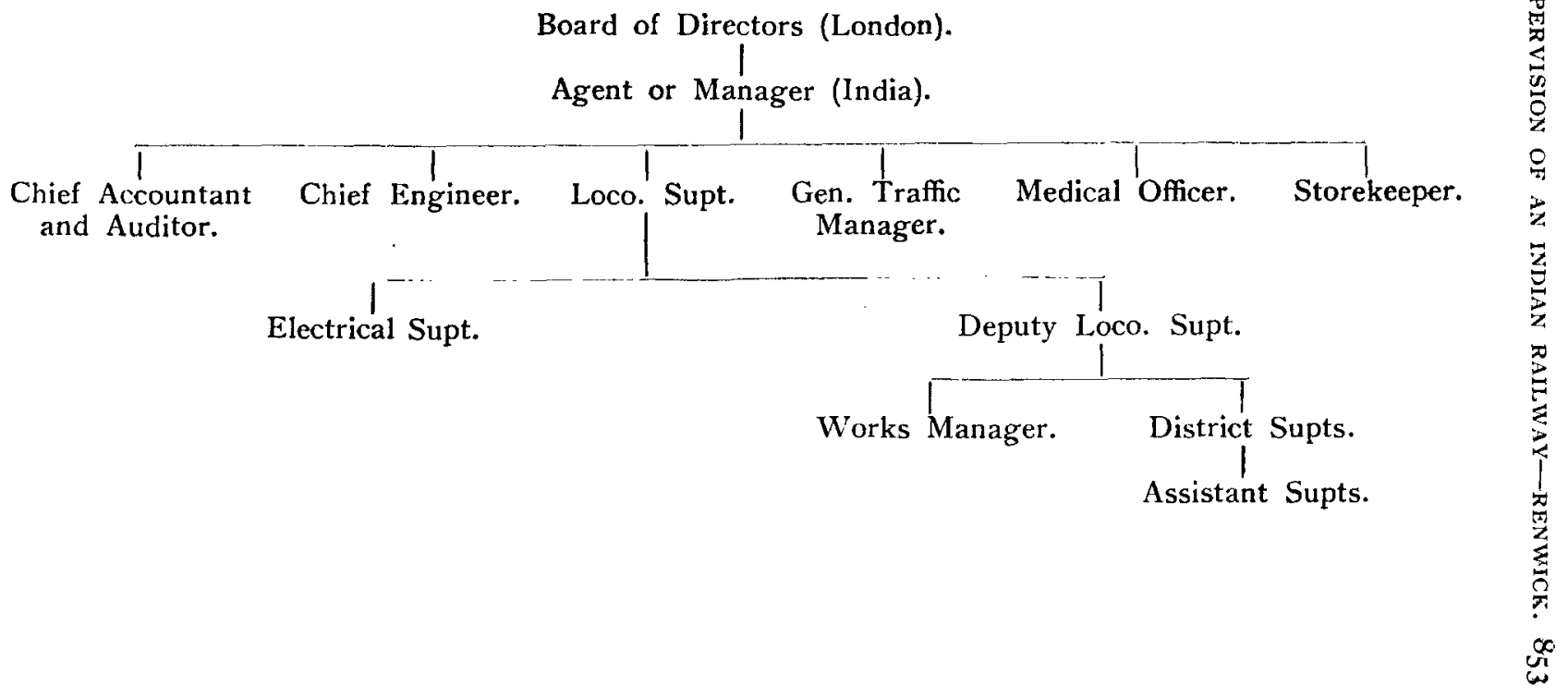


District Supt.

Oilmen.


It may be observed that the one great effect of the temperature is a considerable reduction in the output of work per individual, whether Native, Eurasian or European, and the tendency to slack is one of the greatest evils the divisional superintendent has to combat in his endeavours to obtain the maximum efficiency from his staff.

The organisation of the locomotive department of an Indian railway is usually different from that adopted on English railways, and is diagrammatically shown on pages 853-54.

The departmental system is possibly the best suited to the country, and allocates to the individual concerned a distinct responsibility which can be definitely outlined, but against this is the departmental jealousy that may be engendered and the possibility of the general good of the company sufferisg by the individual zeal for the department.

The subdividing of the company's employees into official and subordinate grades is another feature of Indian railways, and is analogous to the military system of rank, the commanding officer being likened to the locomotive superintendent or departmental head, the major to the deputy, the captain to the district officer, and the subaltern to the assistant officer.

Continuing the analogy, the locomotive foreman or foremen train examiners become the sergeant-majors; the locomotive inspectors, running shed chargemen or mechanical inspectors the sergeants; the senior drivers and maistries (or shed charge hands) the corporals, and the various remainder the rank and file; whilst it is further strengthened by the strong line of demarkation that exists between the commissioned and non-commissioned ranks.

In a somewhat similar manner promotion follows through the various ranks, racial impartiality being shown in the filling up of vacancies in the various ranks with existing European, Eurasian and Native staff of proved capabilities, though, on account of the superior and more specialised training available in England, it is the general practice to obtain officers and some of the shop foremen and chargemen from there. Some of the large railways also obtain a small proportion of drivers and firemen from England.

Considerable variations exist in the mileages of track allotted to a district, convenience of handling being the limiting factor in most cases, as owing to the greater part of the Indian railways being of only single track, district 
limits may be some hundreds of miles apart, with possibly the district headquarters situated at one end of the section instead of more conveniently at the centre.

The G.I.P. Ry. has a route mileage of 3,074 , and is divided into nine locomotive districts, the mileage and locomotives allotted to each being as follows:-

$\begin{array}{llccc}\begin{array}{c}\text { District. } \\ \text { Bombay }\end{array} & \ldots & \text { Mileage. } & \text { Locomotives. } & \begin{array}{c}\text { Running } \\ \text { Sheds. }\end{array} \\ \text { Igatpuri } & \ldots & 198 & 201 & 2 \\ \text { Lonavla } & \ldots & 163 & 127 & 2 \\ \text { Sholapur } & \ldots & 276 & 148 & 2 \\ \text { Bhusaval } & \ldots & 361 & 76 & 2 \\ \text { Jubbulpur } & \ldots & 320 & 254 & 3 \\ \text { Nagpur } & \ldots & 325 & 103 & 4 \\ \text { Bina } \ldots & \ldots & 551 & 99 & 2 \\ \text { Jhansi } \ldots & \ldots & 768 & 106 & 4 \\ \text { District } & & & \end{array}$

District supervision may be complicated by the fact that there are four gauges of track in common use in India$5^{\mathrm{ft}}$. 6in., $3 \mathrm{ft}$. $3 \frac{\mathrm{g}}{8} \mathrm{in}$., $2 \mathrm{ft}$. 6in. and $2 \mathrm{ft}$. -and mileages of each of these four gauges may be worked by one system, as tabulated below.

The district loco. superintendent is held responsible for the whole of the locomotive department staff, train running, locomotive maintenance and water supply, as well as on some railways the whole of the carriage and wagon work throughout the area under his jurisdiction; and in addition the housing of the staff, work in connection with the schooling of the employees' children, and the management of railway institutes and social clubs for the staff, both Indian and European.

As all these items require personal supervision, and as the running sheds or railway centres may be up to a hundred miles apart, a considerable amount of travelling is necessary to cover the ground.

Saloon carriages for his personal use are usually allotted to each district officer, the accommodation provided being such as to enable him to live in the carriage for days at a time and comprising a bathroom, kitchen, pantry and servants' compartments, and a saloon compartment with couches convertible to beds, writing table, cupboards, etc. To the casual observer these saloons may at first sight appear to be unnecessary luxury, but when it is realised that one's work may lie at a point where there is no accommodation for a European, where there is a station without refreshment or waiting rooms, consisting only of a booking 
MILEAGES OF TRACK OF VARIOUS GAUGES ON THE LARGER INDIAN RAILWAYS.

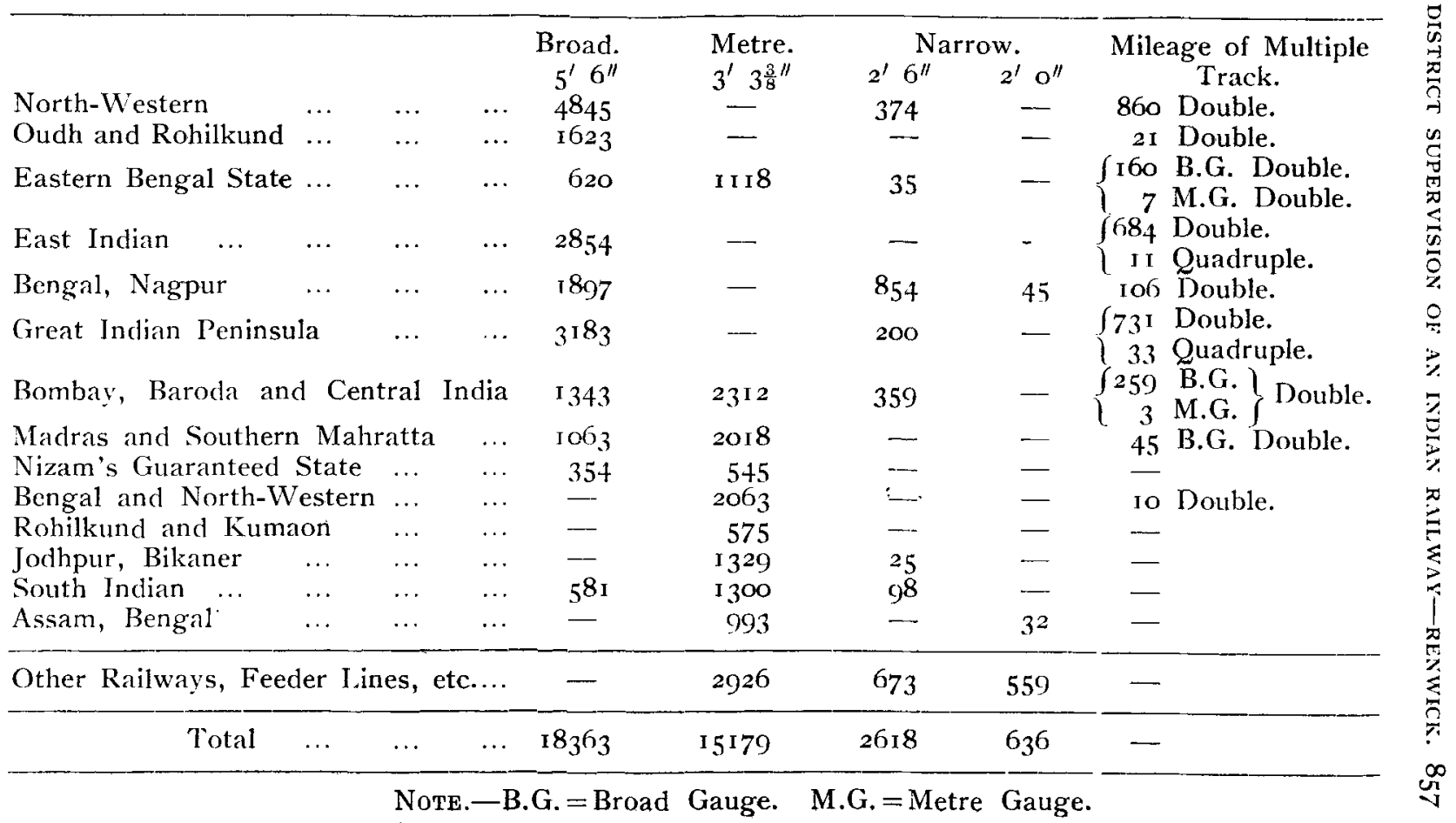


office, and a running shed and drivers quarters; where possibly only one up and dow $n$ passenger train calls during the 24 hours, and those probably during the middle of the night, it will be admitted that some such provision is essential.

It is difficult to present a picture of the average section of an Indian railway so that the conditions can be easily visualised by anyone who has not been connected with Colonial railways. It may be accepted that around the Presidency towns, such as Bombay, Calcutta, Madras and Karachi, or the large inland towns such as Lahore, Cawnpore, Lucknow, Nagpur or Bangalore, there is a distinct similarity with up-to-date English practice. Stations are well built and equipped, points are interlocked, and signalling is in accordance with the latest principles. Away from the main lines, howerer, the traffic does not warrant equipment on such an elaborate scale. Platforms are generally absent, station buildings are of the plainest, generally consisting of the station office, in which the telegraph and block or tablet instruments are located, a waiting room and a lamp room. Signalling and interlocking, where provided, is of. the simplest.

Owing to the necessity of reducing the initial cost of the line and the avoidance of expensive cutting and filling, lines follow the contour of the country, and in consequence stations may be, and frequently are, some distance from the village they serve, and the picture of a wayside station, apparently in the centre of an uninhabited plain, is fairly common.

The track is mostly single and unfenced, and its use as a public highway, especially by cattle, is universal.

Grades vary with the contour of the country, and may be fairly severe, a maximum gradient being settled on during the preliminary surveys. Apart from "Ghaut" sections in hilly country, gradients of more than $I$ in 100 are, if possibie, avoided. On a section of 385 miles of metre gauge line that the Author had charge of, there was no less than 55 per cont. of the maximum grade of $I$ in 133 .

On the "Ghaut" sections, grades of up to $I$ in 25 are met with, and banking or double heading is resorted to in working main line loads over such sections.

The mileage of grades on the larger broad and metre gauge railways is as follows:- 


\section{MILEAGES OF GRADIENTS ON INDIAN RAILWAYS.}

\begin{tabular}{|c|c|c|c|c|c|c|}
\hline $5^{\prime} 6^{\prime \prime}$ Gauge. & & $1-25-$ & $\begin{array}{l}1-51- \\
1-80 \\
\end{array}$ & $1-81-\overline{0}$ & 1-101- & $\begin{array}{l}1-200 \\
1.300 \\
I 50\end{array}$ \\
\hline Bengal, Nagpur & .. & - & - & I 20 & 624 & $15^{\circ}$ \\
\hline B.B. and C.I. & $\cdots$ & 一 & 一 & 一 & 262 & 99 \\
\hline Eastern Bengal & $\cdots$ & - & - & 一 & - & 7 \\
\hline East Indian ... & $\cdots$ & 6 & 19 & $5^{\circ}$ & 219 & 173 \\
\hline G.I.P. $\quad \ldots$ & $\ldots$ & 20 & 3 & $7^{2}$ & 810 & 280 \\
\hline North-Western & $\ldots$ & 85 & I IO & 217 & 2 I I & 135 \\
\hline M. and S.M. ... & $\ldots$ & - & I3 & 34 & I 86 & II 3 \\
\hline O. and R. $\quad \ldots$ & $\cdots$ & - & 9 & 6 & I9 & 22 \\
\hline $\begin{array}{l}3^{\prime} 3 \frac{9}{8 \prime \prime} \text { Gauge. } \\
\text { Assam. Bengal }\end{array}$ & & I0 & & 38 & I 27 & 32 \\
\hline M. and S.M. ... & $\ldots$ & 16 & 81 & 608 & 318 & 117 \\
\hline South Indian & $\ldots$ & - & 29 & 39 & 185 & 83 \\
\hline$B_{4} B$. and C.I. & $\ldots$ & 3 & 二 & 19 & 390 & 234 \\
\hline N.G.S. Rly ... & $\cdots$ & - & - & - & $25^{\circ}$ & I5 \\
\hline B. and N.W.... & $\ldots$ & - & 一 & 一 & - & 7 \\
\hline
\end{tabular}

Running sheds and loco. yards in India are, owing to the facility with which land is obtainable, laid out on generous lines, whilst on account of the unusually long distances that lie between them and the main repair shops, very complete equipment is necessary for undertaking repairs. Ágain, owing to the distance from the centres of supply, large stacking areas are usual for coal, three months" stocks being as far as possible kept in hand.

The open or "through" type of shed is preferred to the "round house" type on account of simplicity of construction and better ventilation possible.

Owing to the heat, sheds are generally larger and higher for a given engine capacity, and open to a degree impossible in England.

A common type has brick or dressed stone side and end walls with open arches, and is roofed with corrugated asbestos sheeting on trusses of about 45 feet span, covering three roads. Along one side are ranged a time office, foreman's office, clerks' office, stores, oil stores, machine shop and engine turners' room.

Another common design is with a steel $L$ or $T$ frame, with trusses supported on brick or stone pillars. It usually has a saw-tooth roof sheathed in corrugated iron, the bright sunlight obviating the necessity of the vertical faces of the roof being glazed, a common filling being of galvanised strips set in louvre formation. 
In this case the offices may be a brick or corrugated iron structure placed alongside the shed, or even a separate building. Another common practice is to utilise the lower portion of the water tank house for the stores and foreman's offices.

Smoke ducts and chimneys are rarely provided as lighting-up and steaming is performed in the open.

Lighting-up is done either with firewood and oily waste, or by means of live coal from a combined lighting-up furnace and sand dryer.

There are also a number of small sheds where no engines are permanently stabled, but where engines stand in steam during the driver's rest period. No repair facilities are, as a rule, provided, and the equipment and staff are reduced to a minimum.

Lifting appliances, such as sheer legs, are not usually provided except at the larger sheds, though drop pits are coming into more general use.

Lifting by four jacks is the most usual method, however, of doing hot box or spring repairs.

Shed lighting has not received as much attention as it might have had. In the few sheds where electric power is available, excellent results have been obtained, but in the great majority of running sheds kerosene oil vapour incandescent mantle lamps of $200, I_{1}, 000$ and I,500 c.p. are the only possible medium. These require a good deal of attention to keep in order, and in the rainy season, with the accompanying high winds, are none too easy to keep alight. In view of the simplicity of a small power house worked by producer gas from smokebox ashes, which are at present a waste product, it is a pity that electric lighting of railway centres is not more general.

Turntables of from $45 \mathrm{ft}$. to $65 \mathrm{ft}$. are of the usual plate girder deep pit type and are manually operated, no powerdriven turntables having yet been installed, to the Author's knowledge.

Recently some $75^{\mathrm{ft}}$. tables have been put into service on the G.I.P. Ry., and these are the largest in the country.

Owing to the ease with which land can be acquired, it is common practice to include a triangle in shed lay-outs, in addition to a turntable.

Repair facilities at running sheds vary considerably, though it is usual to provide sufficient machinery at all running sheds where engines are permanently stabled to cope with fairly heavy running repairs. 
It is also usual to provide district repair shops at three or four points on the system where heavy repairs or overhauls can be undertaken, with an output of five or more engines per month. On the G.I.P. Ry. such shops are situated at Igatpuri, Lonavla, Bhusaval and Jhansi, these stations being district headquarters.

The shops at Jhansi were the locomotive department shops of the Indian Midland Ry., and cannot, therefore, be classed as district repair shops, as the output averages i5 engines per month.

Repair work in the running sheds follows the usual methods obtainable in English sheds, except that specialisation is more usually followed, as " all-round" men are few and when found are more usefully employed in the smaller sheds as leading hands, so that they can tackle anything that comes along. Repairs are entered by incoming drivers in repair books, and the work required to be done is allotted to the fitter or assistant concerned by the chargeman, verbal orders being given.

The card system of allocating work cannot be followed owing to a large proportion of the native staff being illiterate and having no knowledge of English, possibly only knowing their particular vernacular language.

The spread of education, however, is gradually improving matters, and it is usual to find that the maistries and a large number of the higher grade fitters can both read and write English, so that they can take off their own work from the repair books, reporting completion to the chargeman and signing the repair book with the time of completion and staff ticket numbers of the men on the job.

By dividing the fitting and boiler staff into gangs for (1) piston and valve repairs, (2) vacuum brake repairs, (3) axlebox and spring repairs, (4) big end and little end brass, and eccentric sheave and strap repairs, (5) safety valve setting, regulator and pressure gauge repairs, (6) stay renewals, (7) tube renewals, (8) lead plug renewals, better work results and responsibility for bad workmanship can be fixed at once.

Periodical examination is carried out in addition to running repairs either by the leading fitters of each gang or by a special gang.

The former method is the better where the period between examinations is fixed by time, and has the merit of allowing the examination being made during the time the engine is stopped for other repairs; but, on the other hand, it needs close attention on the part of the chargeman 
fitter and boilermaker to ensure each engine being examined regularly. Registers of examination dates, condition and renewals executed are kept and sent to the district locomotive superintendent monthly for his inspection and initial. Where a fixed mileage is adopted between examinations the engine is stopped and gone through from end to end, but this system necessitates the engine being out of service for from three to five days.

Washing-out is, on some railways, done by the driving staff on " shed days," but more usually by the boiler repair staff. Large hot-water washing-out plants, are only used in one or two instances, cold-water washing out being the more usual method, though the Gresham hot-water washing-out injector is frequently adopted.

The general run of Indian running shed fitters and boilermakers cannot be relied on to make as good a job of their work as their English confrères; they are by no means as quick, and do not appear to take much pride in the quality of their work. No doubt the Indian workman, if allowed to do a job in his own way and at his own speed, can be a fair workman; but he needs constant supervision, and possibly owing to the discomfort attendant on most locomotive jobs and the short time usually available, shed repair work is not as well done as it ought to be. The percentage of daily absentees both in the running and repairs staff would appal an English superintendent, especially in the larger towns, where outside attractions are more numerous than in the small and purely railway centres.

Due to sickness, laziness, frequent festivals and small needs easily satisfied, the native averages perhaps only onehalf or two-thirds as many working hours in the year as the British workman, and when working he performs only about one-third or one-half the work of the average British workman in a given time.

Physically and constitutionally the Indian mechanic compares badly with the English fitter, but putting aside his laziness, his loose notions of accuracy and his decidedly looser ideas of truthfulness, he is sober, useful and fairly tractable.

The nut awkwardly placed that cannot be easily got at, and is therefore left only hand tight; the split pin that cannot be properly opened, and is not put in ; the everlasting habit of lapping a bit of string behind a pipe collar and pulling up the union nut to stop a leak; the big end cotter that has its split cotter an inch below the strap, depending on the set screws to hold it in position, are a few of the 
ever-present troubles owing to a lack of thoroughness on the part of the native workman.

There undoubtedly are good men who can be relied upon to use a spanner instead of a hammer and chisel to loosen a nut, who can let together big end brasses so that they do bear properly on the crank pin, and who can bed on a bearing brass that will not run hot on the engine's next trip, and it is a wise chargeman and foreman who gathers such men round him and keeps them contentedly working under him.

It has hitherto been the accepted idea that, owing to the low cost of labour in India, mechanical "labour-saving" devices are unnecessary, but during the last few years wages have risen considerably, and there is a distinctly growing "Labour Union Movement" which will undoubtedly further reduce the " work done, pay received" ratio to a lower level than it is at present.

It would seem, therefore, that mechanical plant should be introduced into India even more than it is being done, for even if the saving in wages is not so considerable as in England, the reliability of mechanical methods alone makes it desirable.

However, in spite of these disadvantages, it is possible to run a district operating 150 locomotives and working $13^{\circ}$ trains a day with an engine failure list of less than five a month and a time-keeping record of 75 per cent. to schedule.

The stores is a section of an Indian running shed that needs considerably more attention than in England, on account of the long distances from the supply centre, delay in receiving materials and large stock that needs to be carried. Not being handicapped for room in the lay-out, an excellent arrangement of bins, shelves and racks can be put in, and materials conveniently grouped.

The method of requisition of materials, whether from the general stores or shops, is by an indent signed by the loco. foreman and countersigned by the district officer on the loco. depot stores attached to the main shops.

These indents describe the material and quantity required, and if for stock for running engine repairs, the quantity on hand and the quantity still outstanding on previous requisition not complied with (if any).

If material is required for a special purpose or to be charged off against any special work order or in replacement of a special fitting such as an ejector, Weir pump, sight-feed or mechanical lubricator broken or sent to the main shops for repairs, etc., the work order number or engine number is 
quoted and the advice note under which the defective material is returned.

Stock registers are maintained showing the balance on hand at the commencement of the week, and receipts and issues during the week. Stores transactions for the month, item by item, are then taken off on forms and submitted to headquarters through the district superintendent for account purposes.

Stock checking is usually done half-yearly by a travelling auditor of the stores department, but the district officer should periodically, when visiting the running sheds, make a minor check of stock on hand to ensure the records being properly maintained and that stocks of material rarely required or obsolete should not accumulate. He should also pass a careful eye over the scrap to see that useful material is not being returned.

It is a point for discussion whether it is better for a running shed to be supplied with finished articles such as side rod bushes, big and little end brasses, axleboxes or axlebox brasses, or with partially finished or even rough castings, which, having the facilities, they can machine up in the shed.

It is distinctly annoying, as the Author frequently found when he was in charge of a section where the loco. superintendent did not consider machinery necessary in a running shed, to receive completely finished side rod bushes amongst other articles, presumably made to gauge in the main shops, but that would neither fit on the crank pin nor go into the rod eye.

However, such days are rapidly passing.

Oil stores are sometimes located separately from the shed, mainly on account of fire risk, but the internal arrangement is more or less the same, the oil being stored in tanks, generally holding sufficient for a three-months' supply. These are preferably arranged immediately outside the shed, and the oil is piped through and issued from the inside of the shed, measuring cans being used for issuing according to the quantity scheduled.

The automatic measuring and issuing apparatus is a distinct improvement and should find a place in all sheds of any size.

Issues are made both for coal, oil and waste on vouchers. These are receipted by drivers, and forwarded with weekly statements to headquarters through the district superintendent for consumption records. 
All issues to shed and train examining staff are made on vouchers or issue tickets signed by the foreman or chargeman.

A rather gruesome sight that might be noticed by a stranger in any Indian running shed stores is a stock of coffins of various sizes.

Life in the East is popularly supposed to be fairly rapid, but owing to the heat interment is quicker still. Undertakers being unknown outside the larger towns, generally some hundreds of miles away, the necessity for the provision can be understood.

There is considerable room for improvement in the method of handling coal in an Indian locomotive shed, in spite of the difficulties that have to be contended with.

Collieries are situated at six points in the country, the largest area lying in the provinces of Bengal, Bihor and Orissa, around Asansol, and served by the East Indian and Bengal, Nagpur Railways.

Collieries are also situated in the Central Provinces at Umaria, Mohipani, Parasia and Warora, served by the Great Indian Peninsula and Bengal, Nagpur Railways, and in the Hyderabad State at Singareni, whilst smaller quantities are found in Assam, Baluchistan, the Punjaub and Rajputana. The quantities mined in $\operatorname{Ig}^{1} 3$ and 1920 are given as follows :-

\section{QUANTITIES OF COAL MINED IN INDIA IN} 1913 AND 1920.

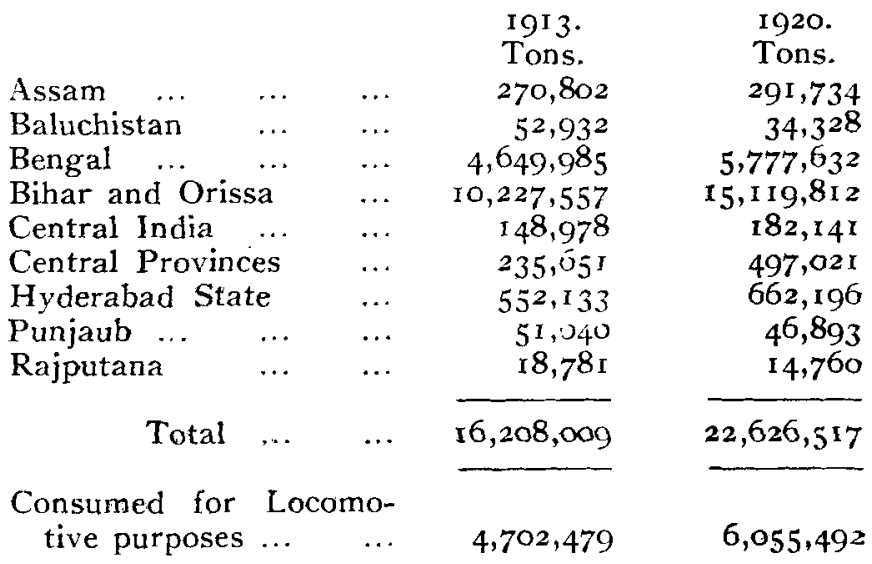


Foreign Coal imported for Locomotive Purposes.

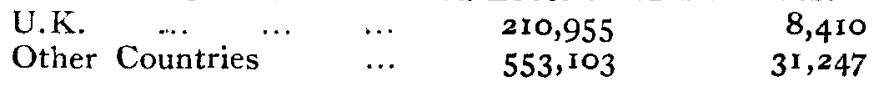

Requisitions for coal for all the sheds on his district are sent quarterly by the district officer to headquarters, the total quantities being proportioned off according to grades of coal required for express, passenger, goods, or shunting services.

Deliveries ex collieries commence during the first week of the quarter, but owing to the distance to be traversed it may be three to five weeks before the wagons reach their destination, always providing that none of the wagons havt been cut off for hot axleboxes and their contents unloaded at the nearest shed; that a washaway during the monsoon period has not held up deliveries, or that owing to shortage at a shed en route, wagons booked to one district are not directed to another.

On receipt, test wagons are taken out and run over a weighbridge for comparison with invoiced weights.

Unloading is then done by hand direct on to tenders or into stack according to quality.

Loading on to tenders is done by basket measurement (28 or 30 to the ton) checked by the muccadam of the coolie gang, or by separate tally clerks, and entered on the issue tickets. These are signed by the driver and accompany the weekly coal return to headquarters.

The locomotive foreman takes a survey on the first of each month of the coal in the depot, by (I) stack measurement, (2) invoiced weight of coal in wagons standing under load, or unloaded but not stacked, and (3) estimate of coal on tenders; and this is again checked quarterly personally by the district officer.

It would seem that the method of buying coal in tons, issuing by baskets and checking by cubic feet would result in hopeless confusion, but it is really extraordinary how correct the figures work out.

At the same time, it is realised that strictly accurate methods are desirable and would be readily adopted were it not for the difficulties to be faced.

These are roughly-(1) cost; (2) small quantities to be handled (50-500 tons per day); (3) irregular receipts, so that loading must be possible either from covered or opened wagons or from stacks situated at various parts of the loco. yard. 
At some of the larger sheds loading is done by crane and buckets of 5-20 cwt. capacity, but so far as the Author is aware no purely mechanical plant of the type evolved by Messrs. Fraser and Chalmers, or as adopted by the London and North-Western, North-Eastern and other English railways is in use in India, mainly from the objections raised by items (I) and (3) above.

A further complication is raised by the indiscriminate use of open and covered wagons for the conveyance of coal, and though not strictly relevant to the subject under consideration, a mechanical contrivance for unloading from and loading into covered wagons would be greatly appreciated for dealing with tranship coal from broad gauge wagous into metre or narrow gauge wagons.

The supply of an adequate quantity of water for locomotive as well as staff purposes on his district frequently occasions a good deal of trouble for the district officer, especially during the hot season.

Speaking broadly, the largest proportion of water used for railway purposes is pumped from wells dug in the vicinity of the station or running shed, or where convenient, taken from rivers or lakes. Artesian wells are not much used except in Gujerat and Kathiawar, it being rarely necessary to go below 50 feet to strike a water-bearing strata.

Owing to the abnormal difference between the river levels in the monsoon and dry seasons it is usual when taking river water to pump either from a well dug on the river bank, or if the railway line crosses the river, to build one of the bridge piers as a well pier and mount the pump and boiler on the top.

In a few cases, in hilly country, reservoirs can be made and the water piped by gravity to the shed or station water columns and quarters.

Town or municipal water supply can only rarely be obtained, whilst the charges for such water make it preferable and cheaper to arrange one's own supply.

Watering stations are generally arranged at intervals of 25-30 miles, no water troughs being at present in use. Auxiliary water stations are ranged at convenient intermediate points.

The uncertainty of the annual monsoon renders it necessary to bring these auxiliary water stations into use during the succeeding hot season, it being usual to water goods trains only at certain stations and passenger trains only at others. 
A bad monsoon or two or more successive bad years may play havoc with all previous arrangements and necessitate the opening of temporary watering places at mileages between stations, tanks being placed on sleeper cribs alongside the line and hand or power pumps installed, according to the amount of water available or the number and frequency of the trains to be watered; whilst in the event of a water failure at a running shed it will probably be necessary to rail water in tanks by special train from the nearest available source, possibly 40 or 50 miles away.

Under such circumstances the use of water is restricted to the minimum, washing out being arranged for at other sheds and staff quarters supply cut down.

Boiler troubles are naturally more common at such times, due to foaming and scale formation from the frequently unsuitable waters that have to be used.

Water softening plants are uncommon, but a very excellent method is the Dearborn treatment, which is largely used. This is effected by briquettes or bars of a special compound made up to suit the water on each section of line, according to its analysis, and put in the tender before each trip, scale being blown out in the form of sludge through the blow-off cocks at the end of each trip. Bricks of a similar nature are used for anti-foaming treatment and are put in the tender at each watering station after filling up.

Accidents are, more or less owing to the relative unreliability of the native staff, possibly more frequent than in England, especially what are termed minor accidents.

Amongst many others are the derailments caused by the pointsman who will reverse hand-operated facing points between moving vehicles, the shunter who backs the tail of his load through the dead end and down the embankment, or the driver who runs through trailing points and promptly proceeds to back his load on to two roads or generally off the road altogether, breakaways due to flawed couplings or mishandling of his engine by the driver, collisions due to drivers starting away without a line clear token on single line, and derailments due to washed out track or culverts during the monsoon season.

Strategic points for the provision of breakdown trains are necessarily very much further apart than in England and therefore much more time is taken in reaching the scene of the accident, whilst, owing to the large amount of single line, it is frequently difficult to get at the point of operation on arrival at the scene of the accident. 
As an instance of this the Author would quote two cases, one of a wagon derailment on a train entering a station yard, the other of a "head on " collision between stations.

In both cases the breakdown train had to arrive from the rear and work back undamaged vehicles five or more miles to the previous station before being able to get to work with the crane.

Another feature is the difficulty of getting precise information as to what has actually happened, especially where the telephone is not available, and messages sent by telegraph arrive badly mutilated in transit by the native signallers.

Breakdown trains are generally as well and completelyt equipped as in England, though steam cranes are few, hand cranes of IO-I 5 tons capacity being more frequently found.

Jacking and slewing or ramping are the most frequent methods adopted in re-railing, and to this end all Indian locomotives are provided with two screw jacks of 10, I5 or 20 tons capacity, and on some lines with two double ramps as well.

Breakdown train gangs are selected from the shed fitters and coolies. Quarters are provided adjacent to the shed, and it is generally possible to get the train away in 45 minutes from the time of receipt of the accident message.

It is worth while recording that the Indian fitter on breakdown work and the Indian fitter in the shed appear to be two totally distinct beings, and the Author has seen some very smart work done at accidents by men whose work was very much the reverse in the shed.

The Indian will keep going under the most disheartening conditions, and working on a bad derailment at night during the monsoon needs to be experienced to be appreciated.

Inky blackness, pouring rain, mud and water everywhere; with sodden clothing, shivering and wretched, he will keep cheerfully pegging away till the job is done.

Courts of inquiry are held in the case of all major accidents and such minor accidents the cause of, or the person responsible for, which cannot be definitely decided at the time.

Accidents are classified in the railway company's working instructions or rule book, and the intimation of an accident is circulated by the station master nearest the point of the accident to the officers and staff concerned by tele- 
graph message, usually referred to as the "all concerned wire." This gives the essential particulars, whether assistance is required, and quotes the section under which the accident applies.

On receipt of the message the inspectors of the traffic, engineering and locomotive department proceed to the site of the accident, where an informal investigation takes place, and if the accident is directly attributable to a fault on the part of the staff or plant under either department, the district officer of that department accepts responsibility and deals with the staff at fault.

Should there be any doubt as to the cause of the accident a formal court of inquiry is ordered to be held by the district traffic superintendent under instructions from his departmental chief.

Courts of inquiries are of three grades: (I) "Senior officers," (2) "Major" and (3) "Minor."

"Minor" inquiries are held by the inspectors of the departments concerned at the nearest point to the site of the accident, and evidence from all grades of staff concerned is taken and summarised and a finding arrived at as to the cause.

"Major" inquiries are held by divisional or assistant superintendents of the departments concerned into more serious accidents, whilst frequently "major" inquiries are ordered into cases that have been previously the subject of " minor" inquiries at which a definite finding could not be arrived at.

"Senior officers" inquiries are held by the heads of the department concerned into accidents of the most serious kinds.

Inspecting officers appointed by the Railway Board (which is analogous to the Board of Trade in England) are notified of all serious accidents occurring in the area under their jurisdiction, and of the time and place of the subsequent inquiry at which they may elect to be present.

The inspecting officer does not, as in England, conduct the inquiry, but sits as an extra member of the committee, questions witnesses where necessary and generally watches the case on behalf of the Railway Board, to which he forwards his report. In cases resulting in loss of life, serious injury, or heavy damage to property or rolling stock, such as are classed " A," the district railway magistrate is also usually present at the inquiry, since under the Railway Act, staff responsible for such accidents are liable to imprison- 
ment or a fine or both, the police prosecution following the inquiry proceedings.

One side of a district superintendent's life in India, which though not coming within the scope of his official duties, cannot be forgotten, is the social relations with his staff.

Away from the larger towns, railway centres may be at points where there is hardly any "civil" population, probably a village of sorts, and where the railway colony has grown up around the station or running shed. Quarters or bungalows have been built for the staff, churches for the Christian staff, dispensaries or hospitals, and a market with stalls for mutton and beef butchers (kept separate on account of the religious susceptibilities of the Hindus and Mohammedans), separate schools for the education of Native and European and Anglo-Indian children, and, lastly, institutes for the recreation of the staff and their families.

As far as possible the headquarters of the district officers of the engineering, locomotive, traffic and medical departments are fixed at the same centres, and the task of administering to the social life of the staff is divided between them.

This will entail membership or chairmanship of the management committees of the schools, institutes, rifle clubs, as well as usually a commission in the railway volunteer corps.

Railway institutes being possibly the only means of sacial relaxation available for the staff, require the expenditure of a good deal of one's spare time to see that they are properly run.

Built by the company and equipped by a grant from the Fine Fund, provision is usually made for a large readingroom and library, billiard-room, and possibly a dance hall with retiring rooms, etc.

Adjacent are tennis courts and a sports' ground for cricket and football. The management is in the hands of a committee with, if possible, a district officer as chairman, and is supported by subscriptions from the members of the staff.

Dances, whist drives, billiard and tennis tournaments, and other social functions are arranged, and travelling troupes of entertainers, cinemas, etc., are only too glad to hire the hall and give shows.

Frequently a co-operative stores is run in connection 
with the institute, enabling the staff to purchase household stores very cheaply.

It will be seen, therefore, that the Indian railway district superintendent lives amongst and knows his staff in a considerably more intimate manner than his English confrère, and under such circumstances can, and I am glad to be able to say, does command a very. deep respect from his staff.

The Indian has a very expressive vernacular phrase, "Ap Mabap hai," which literally means "Thou art my father and my mother," and this roughly gives the attitude of the staff, both English, Eurasian and Native, to the district superintendent. He should be looked up to as a kindly master, a wise and ready counsellor, albeit a strict disciplinarian. He will be consulted on all sorts of subjects entirely outside the scope of his official duties, his advice and his help will be asked on matters so divergent that he needs almost to be part lawyer, part magistrate, frequently financial adviser and assister, sometimes cleric, and withal something of a philosopher and a man of infinite patience and tact.

It is essential that all railway officers in India should have a sufficient knowledge of the "lingua franca" of the country, i.e., Hindu or Urdu, to be able to converse easily, and in addition a knowledge of the particular vernacular of the part of the country he is stationed in is of inestimable advantage.

It will be found that one's native staff will come to one more readily, will converse more freely, and one is more easily able to get the truth of a matter when speaking direct than through an interpreter.

It is to be regretted that so few Englishmen have a "gift" for foreign languages, though the majority of Indian railway officers can speak one or more vernacular languages sufficiently fluently for conversational purposes.

Altogether the work of a district locomotive superintendent in India can be considerably more varied and interesting than that of his English confrère, albeit generally more strenuous, and so far as obtaining ideal results, a little disheartening.

However, a generous optimism and considerable patience help to maintain the steady advance of railways in India since their inception and to bridge the small gap required to bring them to the high standard of excellence that characterises English railways. 